UDK 781:929 Debussy C.:130.2

\author{
Marcel Cobussen
}

Univerza Leiden, Nizozemska

Leiden University, The Netherlands

\title{
In(-)formations The Meaning of Paratextual Elements in Debussy's Syrinx
}

Ključne besede: dekonstrukcija, paratekst, dihi, Syrinx, Debussy, Genette, Derrida, ornamentacija, naslovi, priložnostna glasba, binarne opozicije, Pan.

POVZETEK

Po Gérard Genette je mogoče paratekstualne ravni opredeliti kot nekaj, kar je nasproti, ob ali dodano $\mathrm{k}$ 'samemu' tekstu (partituri). V tem pomenu je paratekst vselej podrejen 'svojemu' tekstu. Paratekst je vse drugo razen 'dejanskega' teksta in je tesno vezan nanj; platnica, avtorjevo ime, naslov, predgovor, ilustracija, note itn. Lociran je med notri in zunaj, v prostoru med še vedno in še ne pripadajočemu $\mathrm{k}$ tekstu. Članek $\mathrm{v}$ prvi vrsti obravnava, kako so paratekstualne ravni (zlasti cezure) potrebne za glasbeni tekst ( $v$ tem primeru: za Debussyjev Syrinx za flavto) s (časovnim) pomenom in kako uravnavajo možne interpretacije. Nadalje članek sugerira tudi to, da 'sam' glasbeni tekst vselej že vsebuje parateks (na primer: ornamentaija). Pri skladbi Syrinx so meje med tekstom in paratekstom izredno krhke, ponujajoč vredna vprašanja in pomikanje hierarhije ravni identificiranja teksta.
Keywords: deconstruction, paratext, breath marks, Syrinx, Debussy, Genette, Derrida, ornamentation, titles, incidental music, binary oppositions, Pan.

\section{ABSTRACT}

According to Gérard Genette, paratextual elements can be defined as that what comes against, beside, and in addition to the text (a score for example) 'itself'. In that sense, they are always subordinate to 'their' text. The paratext is all material other than, though very closely connected to, the 'actual' text: the cover, the author's name, the title, preface, illustrations, notes, etc. It is therefore located in the space between inside and outside, the space between still belonging and not yet belonging to the text.

This essay first of all investigates how paratextual elements (especially breath marks) are necessary to provide a musical text (in this case Debussy's Syrinx for solo flute) with a (temporary) meaning and how they direct possible interpretations. Secondly, this essay also suggests that within the musical text 'itself', paratext is always already present (for example in ornamentation). However, in Syrinx, the borders between text and paratext are remarkably porous, creating a noteworthy questioning and shifting of hierarchies. 


\section{1}

... It all starts with the A and B (not) resolving on the A flat in the very first bar ...

First in(-)formation. What is the status of this remark? What is 'the truth' of this statement, if there is any? Let's start (But didn't we already start? Hasn't it started yet? Wouldn't it be better to write "let's continue," not only here, in this particular case, but always? I must return to this line of thought in more detail in a moment) with some objections, some comments to put this blunt opening sentence into perspective, that is, provide it with a frame, because the borders of any context open out wide.

One of the most obvious limitations that can be applied is, of course, the score, that piece of paper offering an indispensable reference, according to which, in this case, it would be immediately clear how wrong my first sentence is. For, preceding the aforementioned interval, a B flat will be discerned, this note being the 'actual beginning' of the piece. It is not with the interval A-B but with the B flat that the composition opens, even fastening itself down on this tone as the tonal center for at least one beat (if not for the majority of the bars). However, if you allow me to dwell upon this for a moment, the question is legitimate: whether this tone effectively marks the commencement, or, more broadly speaking, if any first tone indicates the border between inside and outside, between that belonging to the composition, the aural artwork, and that which is excluded from it. According to Edward Cone, for example, the frame separating music from its external environment is silence. This silence, preceding or coinciding with the musician's first gesture or breath, serves as a call to attention; it focuses the listener toward what will follow. However, Cone speculates that "perhaps some of the silence immediately before [...] a composition is actually a part, not of the frame but of the work itself" (Cone 1966: 17-8). In other words, Cone is suggesting here that silence, initially presented as a frame around music, that is, not belonging to the music 'itself', sometimes becomes part of it. Some confusion arises between inner and outer, between frame and framed; the borders seem to be porous. ${ }^{1}$ Projecting this idea on the work I am discussing here could lead to the conclusion that it does not seem 'to start' with a B flat (either) but with a silence, a silence that can never be total as it is always already permeated by sounds, by noise, if only because the performer must inhale in order to commence playing. This immediately triggers the question of what exactly we mean by 'a work' or 'a composition', as these words still seem to assume discrete boundaries and fixed identities.

\section{2}

Second in(-)formation. Already right from 'the start', we seem to be going from bad to worse, we seem to enter places, following traces, we would rather ignore. Let us therefore go back, back to the safe site of the score, back to the written part, where the beginning of a piece of music is clearly indicated. At least so it seems ... Because, where does the score begin? Simply with the first note, in this case the B flat? The score, a simple copy of Edition Peters, lying here next to the computer, contains a plethora of information before the $\mathrm{B}$ flat note: the time (3/4), the key (five flats, indicating D flat or B flat minor), the clef (treble or G), a concise

1 See for an extensive discussion of this topic Littlefield 2001, especially Chapter 3 on silences as musical frames.

There are many examples where the border between music and not-yet-music is blurred. For Sequenza III (1966), for example, written for solo female voice, Luciano Berio prescribes that throughout the welcoming applause while the performer walks onto the stage, she should be rapidly muttering fragments of words as if she was not thinking about her performance at all. The audience is unsure if the composition has started already? And when exactly? Perhaps her murmuring already began in the dressing room, perhaps even days before the performance. Or should one decide that the mumbling has to be excluded from the composition? But then, where does the work begin? We are confronted here with a complex theme of undecidability, all the more complex because the Sequenza III example makes us also aware that any opening silence is always already permeated by an, in principle, infinite number of sounds. 
tempo indication ('Très modéré', very moderately), the name of the composer as well as his year of birth and death (Claude Debussy, 1862-1918), the instrument for which the piece is written ('Flûte seule', solo flute), a dedication ('à Louis Fleury'), and, between these last two, in capitals, the title of the composition (Syrinx). And this enumeration even ignores the cover, which includes - in order of importance, judged according to the size of the letters and the position on the page - the title of the work, the composer's name, its year of production (1912), for which instrument it is written (in three languages) and by whom it is edited (Erich List).

Gérard Genette would probably call these indications and signs paratext - what comes against, beside, and in addition to the text (the score) 'itself'. ${ }^{2}$ Paratextual elements are always subordinate to 'their' text, they are devoted to the service of something else, and this functionality, he writes, determines the essentials of their characteristics and of their existence (Genette 1991: 269). The paratext is all material other than, though very closely connected to, the 'actual' text: the cover, the author's name, the title, preface, illustrations, notes, etc.; in short, the elements which surround the text - already textual but not yet 'the' text.

However, a score rarely appears in its naked state, that is, without the reinforcement and accompaniment of a certain number of paratextual elements of which one cannot always be certain whether they should be considered as belonging to the text or not. In any case, they are there precisely in order to present the score, that is, to make it present, to assure its presence in the world, its possible performance and reception (Genette: 261). These elements do not leave the score untouched and as such form an integral part of it that cannot be easily separated from the body of the work, the text 'itself', the 'pure' score. In fact, the paratext is the fringe of the text which, in reality, controls the whole reading. In the case under consideration, this is especially true with regard to specifically musical signs: time, key, clef, and dynamic signs, but also with regard to slurs and breathing indications. It would be very difficult to maintain that these elements are, as Kant would call them, Nebengeschäfte, things that come as an extra, exterior to the proper field. In fact, they immediately and necessarily intervene in the interior. One is compelled to establish that the notes on the staff need these supplements. The effect is clear: the borders between 'text' and 'paratext' blur.

Of course, all this applies somewhat less in the case of the editor, the composer, and (even) the title of a composition. But, in Genette's words, they form the 'vestibule' which offers performers and other readers the possibility either of entering the score or of turning back (Genette 1991: 261). ${ }^{3}$ In this sense, they provide the composition with a more or less necessary context (this applies especially to the indication of which instrument is to be played), a context which itself is always already textualized. ${ }^{4}$ But these elements, too, are quite difficult to detach. Without them, something would be lacking, lacking in the very interior of the work; and changing them will lead to different meanings of the text, different performances, different readings, different interpretations. Title, dedication, year of realization, the name of the composer: they are separated from the integral inside, from the body proper. However, they are also divided from the outside, from other works by the same or another composer, and then, step by step, "from the whole field of historical, economic, political inscription in which the drive to signature is produced," in short, the general text (Derrida 1987: 61). With respect to the notes themselves, these paratextual elements merge into the general text. With respect

2 Actually, Genette would probably reserve the word peritext for this kind of information that finds its place around the text/score 'itself'. Besides peritext, paratext consists of epitext, all kind of messages that are situated outside the physical object in which the text/score appears (Genette: 264). In this text I will not make this (in itself problematic) distinction and simply use the more general term paratext.

3 A vestibule is a hall or a lobby from which doors open into various rooms (OED), stemming from the Latin vestibulum, meaning entry or gateway. A host welcomes his guests in the vestibule before leading them into the more private rooms in his house. The vestibule could be called a para-site.

4 Derrida points out that in French 'context' can be heard as 'ce qu'on texte', that which one puts in text, that which one textualizes. 
MUZIKOLOŠKI ZBORNIK • MUSICOLOGICALANNUALXXXXI/ 2

\section{A Louis Fleury}

\section{SYRINX}

Flûte seule

Très modéré
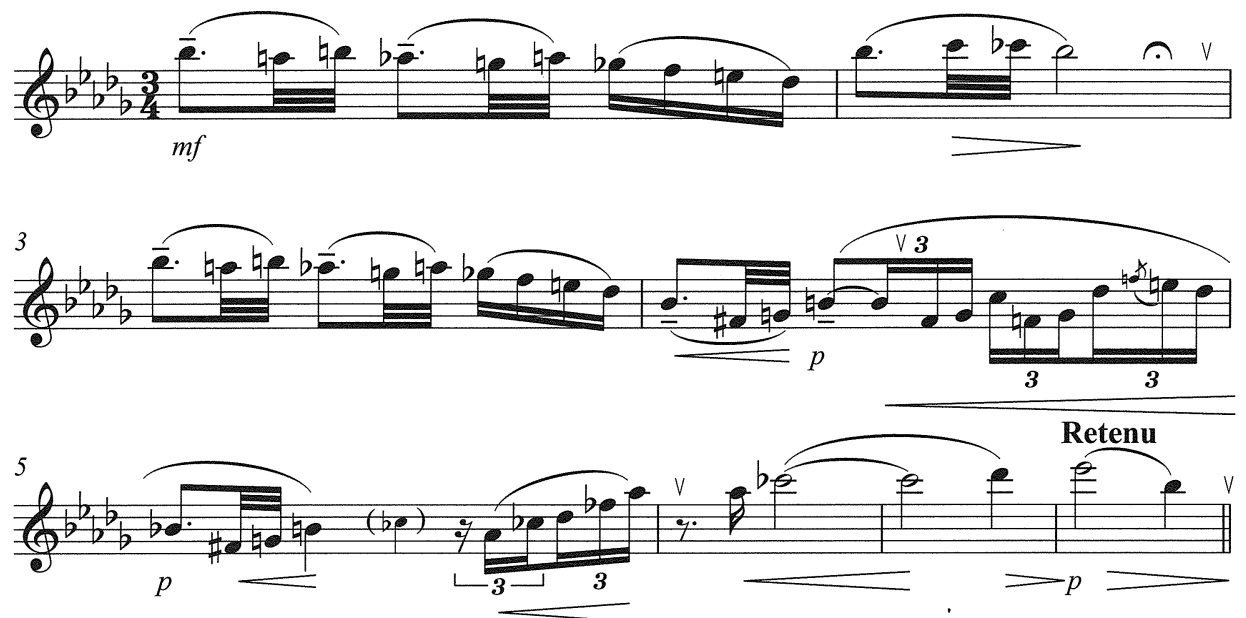

$9 \quad$ Un peu mouvementé (mais très peu)
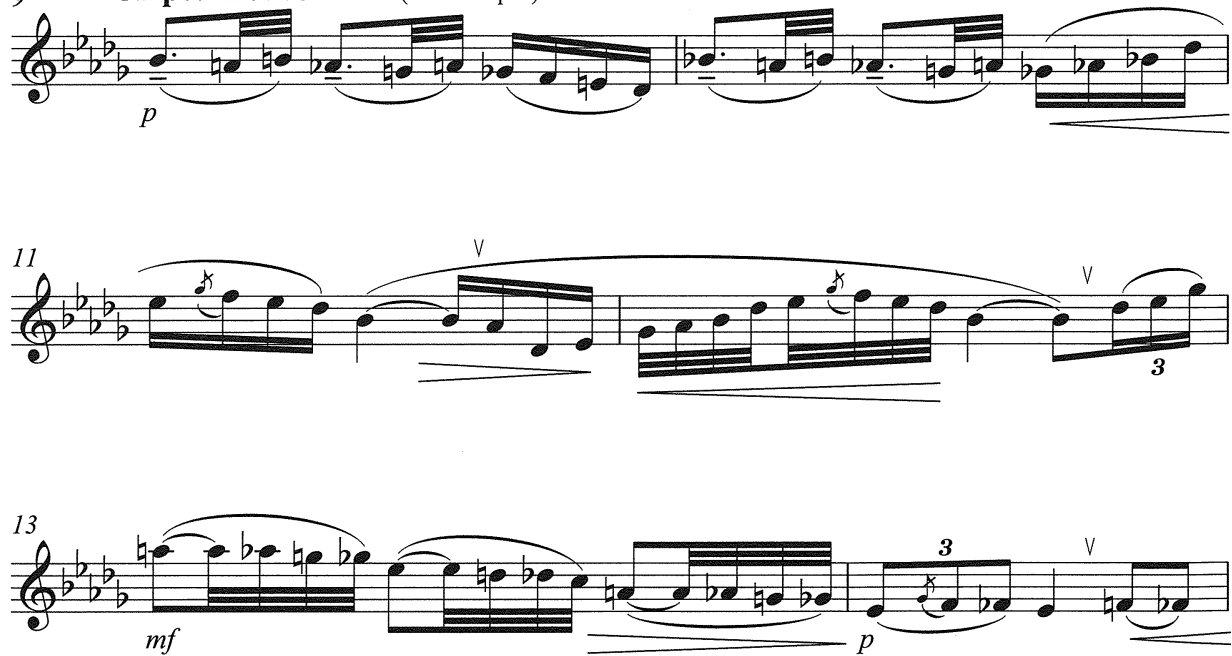

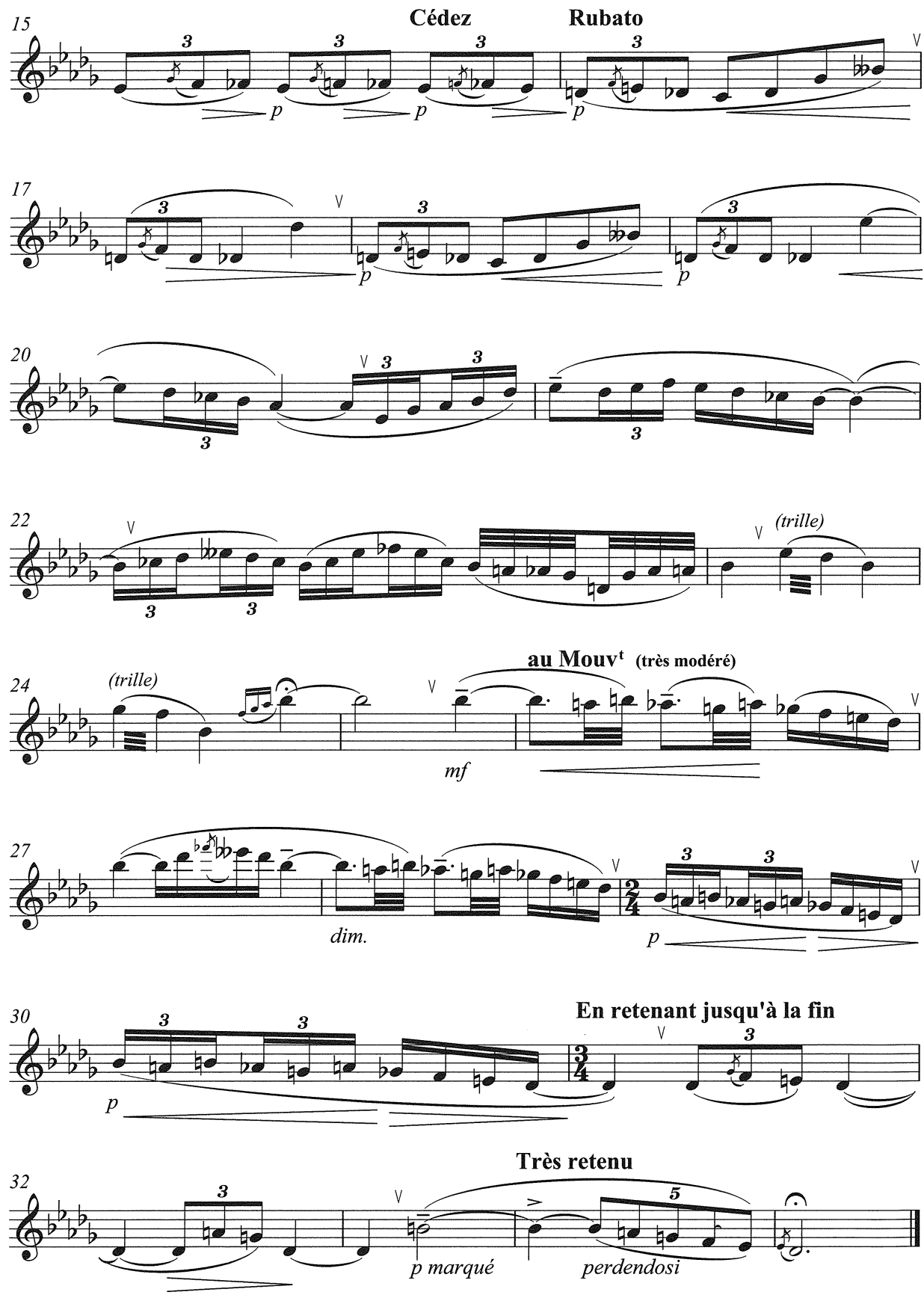
to the background, what the general text is, they merge into the work proper which stands out against the general background (Derrida 1987: 61). ${ }^{5}$

\section{3}

The fundamental undecidability of the exact verges that separate text and paratext - an undecidability which ultimately traverses and thwarts the foundations of our Western thinking based on hierarchically organized binary oppositions (as, for example, the prefix 'para' clearly shows) - at least also undermines the status of my opening sentence. Neither the 'music itself' nor the 'score itself' gives rise to the idea that the A-B interval in the first bar can be considered a beginning. This becomes all the more evident when we dwell upon one particular (para)textual element of the score: the title.

Third in(-)formation. Syrinx. Assuming that a listener already knows the title before hearing the music or discovers it after a first introduction, this title immediately leads him or her to 'another beginning', another world outside of the score, outside of music even.

Almost obviously, and perhaps primarily, the title Syrinx refers to that little instrument consisting of a set of small pipes bound together typically in a row, arranged from smallest to largest, set into musical vibration by blowing across the top of the pipes. These days the instrument is better known as panpipes. Pan's pipes. The pipes of Pan, son of Hermes and the nymph Dryope, god of the woodland and flocks. Although still connected to music - after all, Pan is a god of music as well - we are also entering the realm of literature and cultural history here; the domain of Ovid for example. He provides the main literary source of the dramatic confrontation between Pan and the most celebrated of all the hamadryads of Mount Nonacris in Arcadia, Syrinx. Pan, also a god of sensuality and sexuality, tries to seduce her. Unfortunately for him, Syrinx has proclaimed herself a virgin for life and immediately flees at the first signs of his lustful advances until she is trapped by the calm waters of the sandy Ladon River. Desperately, she begins to pray frantically to the water spirits in the hope that they will save her from the arms of her approaching persecutor. The water nymphs answer her pleas and, just at the moment Pan wants to pounce, they transform her into a bed of marsh reeds. When Pan tries to seize her, he finds in his hands only a river reed. While he is lamenting his loss, the wind, moving across the reeds, releases a clear, plaintive sound. The beauty of the sounds moves Pan to construct an instrument by plucking a handful of reeds, cutting them into different lengths and fastening them together with wax. This instrument made of reed pipes now bears either his name or the name of his forever-lost love.

Playing the pipes, gently touching the reeds with his lips, being charmed by its sweet tones; that way of communing with Syrinx is all that is left to Pan. In his reading of the myth of Pan and Syrinx, as it is told in Ovid's Metamorphoses, Ernst Bloch locates, in the basic human condition of yearning, one of the oldest impulses of music. The sounds of the pipes themselves effect a consolation in Pan by bringing the presence of the nymph to him, even in her absence: "This pipe-playing is the presence of the vanished; that which has passed beyond the limit is caught up again by this lament, captured in this consolation. The vanished nymph has remained behind as sound, she adorns and prepares herself within it, plays to need. The sound

\footnotetext{
"Para is an antithetical prefix which indicates at once proximity and distance, similarity and difference, interiority and exteriority, something inside a domestic economy and at the same time outside it, something simultaneously this side of a boundary line, threshold, or margin, and also beyond it, equivalent in status and also secondary or subsidiary, submissive, as of guest to host, slave to master. A thing in 'para', moreover, is not only simultaneously on both sides of the boundary line between inside and out. It is also the boundary itself, the screen which is a permeable membrane connecting inside and outside. It confuses them with one another, allowing the outside in, making the inside out, dividing them and joining them," writes J. Hillis Miller (Miller 1999: 219).
} 
comes from a hollow space, is produced by the fecundating breeze and still remains in the hollow space which it causes to resound. The nymph became the reeds, the instrument, like her, is called syrinx" (Bloch 1986: 1060).

Syrinx is present in her absence, audible without speaking, visible without showing herself, tangible although her body is not there anymore. Audible silence, visible invisibility, palpable absence. (Making) music represents not only the desire for a presence which is unfortunately eternally postponed; playing the reed pipe comforts Pan and forms, as it were, a substituteconjunction with the nymph who is thus both present and absent.

Thus, (this) music seems to help us catch a glimpse of a deconstruction of traditionally opposite pairs, terms that previously seemed to exclude one another, concepts that were radically incompatible. By means of music, or even through music, we are invited to leave, at least for a moment, our age-old logocentrism.

Let's return once more to Genette's (para)text: "The temporal situation of the paratext may also be defined in relationship to that of the text. If one adopts as point of reference the date of appearance of the text, that is to say that of its first, or original, edition, certain elements of the paratext appeared (publically) at an earlier date" (Genette 1991: 264). Some paratextual elements may emerge prior to the 'actual' text. Genette mentions as examples prospectuses, advertisements that a text is forthcoming, and elements linked to a prepublication in a newspaper or review.

From the foregoing it seems obvious that certain elements of Syrinx paratext appeared at an earlier date. Unmistakably, the title leads us back to earlier times, the times of Ovid, and before him, the times when the gods still visited humans and seduced nymphs on a regular basis. In fact, Syrinx takes us to an untimely or timeless era, as Pan's mythical world does not belong to our calculations of time, to our chronometry, to our calendar. Syrinx takes us to a time that is out of joint. Music and title, collaborating, each one in its own specific way, carry us away from our familiar time scale.

But, at least with regard to this composition, certain elements of the paratext appeared not only at an earlier date; the opposite is also true. That is, certain paratextual elements can also turn up at a later date, posthumous. For example titles. For example Syrinx. In 1927, the year after Louis Fleury's death - the flutist to whom Debussy dedicated the work - the publisher Jean Jobert printed the piece, presenting it under the title Syrinx. A falsification of history? In any case, this is not the name with which Debussy adorned one of his few compositions for theatre. La flûte de Pan was to be performed as part of a scene from Psyché, a dramatic threeact poem by Gabriel Mourey. Thus, La flûte de Pan/Syrinx was conceived as incidental music. ${ }^{6}$ Mourey's poem recounts the myth of Psyché as told by the Latin author Apuleius in his Metamorphoses, inserting the story of the death of Pan, according to Plutarch's version, in the third act. The program also indicates the inclusion in Act III of a composition for flute titled $L a$ flutte de Pan by Debussy. So, not Debussy but Jobert named it Syrinx. The alteration may have been made by the publisher in order to avoid confusion with another Debussy piece, also published by Jobert; 'La flûte de Pan' was the title of the first of the three Chansons de Bilitis, for voice and piano.

\footnotetext{
6 In a letter to Mourey, dated 17 November 1913, Debussy writes: "Please tell me, very precisely, after what lines the music starts. After several attempts I think that one should stick to the Pan flute alone, without any accompaniment. This is more difficult but more [logical crossed out in the autograph] according to nature."

The request for the precise placement of the music suggests that the genesis of La flute de Pan evolved in close association with Mourey's corresponding text.
} 
So, another nymph is involved, another one at stake. Not Syrinx, but an anonymous naiad, a river nymph. In Pan's grotto, she meets an oread, a mountain nymph, who encourages her to listen to the sound of Pan's flute. Like Syrinx, the naiad is fearful of Pan, but the oread assures her that she will no longer be afraid once she has heard him playing. And indeed, as Pan begins to play, the naiad is seduced by the music and surrenders herself without fear. Only a few notes dissolving into a warm night, full of brilliant stars, are sufficient to change the attitude of the naiad completely; she cannot help but become inebriated and overcome by Pan's music. The sound of Pan's flute weakens the naiad's resolve not to give in.

This is the mythical world evoked by Mourey's play, relying freely on Apuleius and Plutarch. It is into this story that Debussy's composition for solo flute is inserted. Though Mourey lets the naiad and the oread refer to the confrontation between Pan and Syrinx in their conversation, in this play, in the music that accompanies it, Syrinx has no actual role.

Of course, although with the best of intentions, Jobert's act is far from innocent. As the frame - the context, that what surrounds the text, but also always already an undetachable part of it - changes, the meaning of the text 'itself' alters; the reading of the text 'itself' is heavily influenced. As such, a title offers guidance, attempts to control the reader's or listener's approach to the score/music. No title leaves him or her unaffected or fails to influence. Modifying the title thus immediately and indisputably affects the meaning of the prescribed notes and, therefore, their performance. The same applies to the fact that La flute de Pan/Syrinx is incidental music, composed to accompany in a certain way a poetic text, a theater play, a mythical story (re)told by a symbolist poet. $^{7}$

If, thus, the context is contributing to and, to a certain extent, determining the meaning of a text, one could state that 'everything begins' with the context. But, assuming that a context is never fully determinable, never totally closeable (in the same way that a text is never a complete whole), its boundaries always porous - assuming that a context is always already framed by other contexts which in their turn are limitless, and so ad infinitum, how can we ever conclude that something 'begins'? It has always already begun. Hence nothing begins. Also this third in(-)formation seems to belie the claim of the opening sentence that it all starts with the A-B interval in the first bar.

\section{4}

And yet ... something always begins, something is always in the state of beginning. In a way, beginning is unending. We are always beginning again, always setting out, always starting afresh. However, this endless beginning must not be confused with origin. On the contrary, beginning, which is never original, marks and remarks the constant disappearance of origin (Taylor: 97).

As a non-original beginning; that is how my opening phrase should be understood. Something has always already begun, but simultaneously that same something is always

\footnotetext{
It should be clear that this short in(-)formation regarding the context within which Debussy's work for solo flute first appeared, does not lead one to the one and only truth on La flute de Pan/Syrinx. Of course, it is evident that a context can never establish a univocal and fixed meaning of a text, although, as Derrida states, it seems that the field of ambiguity or polysemy permits itself to be reduced massively by the limits of what is called a context. However, relying on the context as a protection against what Derrida calls 'dissemination' provides no watertight guarantee. First, as Derrida makes very clear, the prerequisites of a context are never absolutely determinable: any given context is always already open to further description. Second, a written sign always already carries with it a force of breaking with its (original) context. Every sign, linguistic or nonlinguistic, as a small or large unity, can break with every given context (this becomes evident with citations), and engender infinitely new contexts in an absolutely nonsaturable fashion. Derrida warns us that through the values of 'conventionality,' 'correctness,' and 'completeness', the quest for an exhaustively definable context, for an absolutely full meaning that is master of itself, for intention as the organizing center, is lurking (Derrida 1982: 307-330). Here, I only want to emphasize how context is at least also constitutive for a certain meaning. In Genette's words: "I do not say that one must know it; I only say that those who know it do not read in the same way as those who do not" (Genette: 266).
} 
already just beginning (again). It is not so much a step further as a return, a renewed paying attention, an andenkendes Denken as Heidegger would put it, as opposed to a forgetting in the sense of disregard or negligence.

Fourth in(-)formation. "It all starts with the A and B (not) resolving on the A flat in the very first bar." How to read, how to understand this sentence? Or, how to underline the deconstructive force of this interval, here at this position, in this com-position, stuck between a B flat and an A flat, but also at work later on within the piece in a more generalized form?

In the same way that the $\mathrm{C}$ and $\mathrm{C}$ flat in the second bar lead (back) towards the half note $\mathrm{B}$ flat, the thirty-second notes $\mathrm{A}$ and $\mathrm{B}$ of the first beat in bar one could be initially regarded as leading tones of the B flat. After all, the embellishment of a tone usually leads to a confirmation or reinforcement of that tone, endorsing it as a (temporary) tonal center. Here the listener, armed with this theoretical baggage, is immediately put on the wrong track. The putative ornamentation of the $\mathrm{B}$ flat leads precisely away from this tonal center. If the $\mathrm{A}$ and $\mathrm{B}$ should still be called an embellishment, exactly what are they embellishing? With their (non)resolution on the A flat, they become immediately more or less independent, at least partly disposed of their marginality or supplementary character. Their relation with the B flat is not one of ornamentation and (therefore) of mere subordination. ${ }^{8}$ However, this does not directly imply that $\mathrm{B}$ flat on the one side and $\mathrm{A}$ and $\mathrm{B}$ on the other are fully equal; their respective positions in the bar as well as their lengths still justify the opinion that the B flat is more important than the other two. However, these last two notes are not simply in the service of the former one. ${ }^{9}$

$\mathrm{A}$ and $\mathrm{B}$ present a movement to 'something else'. What this 'something else' is, is as yet unknown. But a corner of the veil is raised when the rest of the first bar is taken into consideration. On the basis of the strong beats an outline can be descried as progressing from $\mathrm{B}$ flat through A flat and $\mathrm{G}$ flat to $\mathrm{E}$ (this last one on the first level of the pulse division, the eighth notes): part of a whole tone scale. Simultaneously, the remaining notes of the bar form a complementary whole tone scale: $\mathrm{B}-\mathrm{A}-\mathrm{G}-\mathrm{F}$, ending on what can in retrospect be called the subsidiary tone center $\mathrm{D}$ flat. All the more, this seems to undermine the idea that the notes on the weak parts of the beat merely embellish the others. However, as stated before, each member of the first whole tone scale has rhythmical prominence over the complimentary one something even reinforced by the tenutos on B flat and A flat - thus articulating the primacy of $\mathrm{B}$ flat as the tonal center.

Could we assert that the A and B set an irrevocable process in motion? En route to the end of La flûte de Pan/Syrinx, the signs are already audible: bars 29 and 30, for example. The tone material is identical with the very first bar, but the change in rhythm is significant. In bars 29 and 30, the A and B (as well as the G and A) - thirty-second notes in bar one - are equal in length to the B flat and A flat - dotted eighth notes with tenutos in the first bar - thereby giving greater prominence to the complementary whole tone scale, something also endorsed by the tie linking $\mathrm{D}$ flat at the end of bar 30 with the first beat of bar 31. D flat, the terminus of the melodic descent in bar one, is fully revealed as the primary tone center in the concluding measures of the composition. Like B flat in the opening measures, D flat is stressed dura-

\footnotetext{
In fact, the choice of the $\mathrm{B}$ already indicates that this is not a (mere) matter of ornamentation. If Debussy really intended simply to embellish the $\mathrm{B}$ flat, he would have most probably chosen to write a $\mathrm{C}$ flat instead,

9 What I am contending here with regard to B flat, A, and B in the first beat of bar 1 (as well as bars 3, 9, 10, 26, 28, 29, and 30) applies, mutatis mutandis, to the A flat, $\mathrm{G}$, and $\mathrm{A}$ of the second beat.
} 
tionally in bars 31 and 32 and definitely corroborated as tonal center in the final measure where it becomes the pitch with the longest duration in the whole piece.

Gradually but unrelentingly, a shift takes place in La flûte de Pan/Syrinx, a shift from one center of gravity to another, not a shift to the relative key as the transposition from B flat to D flat might suggest, but a shift from one whole tone scale to another, to the other, to the whol$l y$ other, as the two whole tone scales have no pitch in common. Everything the whole tone scale on B flat had to exclude in order to be 'itself', in order to keep its specific characteristics, maintain its own identity, presents itself in full splendor in the last five bars, though soft, modest ('très retenu'), and gradually dying away ('perdendosi') at that, as if the inversion that has taken place should not be audible. The secondary or supplementary notes of the first bar(s) Could we perhaps call them, paraphrasing Genette, para-notes? - become the dominant or primary notes in the last bars, but without claiming all attention; after the self-confident return of the initial theme in bar 26, preceded by a repeated sounding of B flat in bars 24 and 25 , the take-over happens whisperingly, almost inadvertently. Though we could say that the original hierarchy is subverted, it is not the resounding victory of the underdog; it is as if this 'other' wants to offer the possibility to the listeners to remember, to (re-)hear in the inner self, what play between two scales, what dance between two forces, has formed this outcome. As if it becomes clear, in retrospect, that the A and B in bar one were never actually subordinate to the B flat, but necessary for the whole motivation of the musical process; that 'the other' was always already an indispensable part of 'the same', serving the narrative plot, prompting the initially dominant part to act, to leave its cozy nest, in order to risk a confrontation or, less polemically, an encounter.

The play of the varying tonal centers, the dance of the scales, supplemented with chromaticisms and tritone relationships, permeates the whole piece and serves to undermine the tripartite division, a division upon which almost all analysts agree in recognizing on a macroformal level. ${ }^{10}$ The appearing and disappearing of the respective scales or tonal centers forms a withdrawal from the straitjacket of the most natural division A (bars 1-8) - B (bars 9-24) - A (bars 25-35). For example, B flat, arguably a very important note in bars 1-11, is lacking in bars 13 - 20. From bar 20 on, the B flat becomes more important again (it emerges more frequently, on strong beats, and is sustained longer). However, it decreases again in significance from bar 29 on before disappearing completely from bar 31 on. Analyzing the course of this tone immediately leads to a transection of the proposed macroform; it disrupts the proposed analysis of form, traversing the projected boundaries like a nomad crosses borders.

The obstacles to maintaining clear-cut divisions brings Luisa Curinga to the remarkable conclusion that "probably the best thing would be to perform the piece as a single unbroken discourse, a long fluid phrase in which divisions are instrumental, useful to give the player a mental picture, but to be highlighted the least possible in the performance" (Curinga 2001).

It is on the basis of an ostensibly lost manuscript that it seems legitimate - at least according to Curinga - to consider the piece as an unbroken melodic line. Though her idea is based

10 In 'Parallel Paths ..., Luisa Curinga shows that in the main analyses of La flute de Pan/Syrinx considerable differences can be found in the formal segmentation, obviously due to different approaches and to completely different analytical methodologies used. Nevertheless, most analysts at least agree that new sections begin after bar 8 and bar 25, thereby arriving at a tripartite division A (bar 1-8) - B (bar 9-24) - A (bar 25-35) (Curinga 2001). Should one consider this a Classical sonata form, consisting of an exposition, development, and recapitulation, the last section would surely strike the eye (ear) the most. During the recapitulation in Classical form, a piece returns to reestablish both the original tonic key as well as the original theme. The materials of the exposition are repeated, but the secondary key must now conform to the protagonist's tonic key area. It is absorbed, its threat to the opening key's identity neutralized (McClary 1991: 69). In the third part of La flute de Pan/Syrinx, the original theme is transformed in such a way that the complementary whole tone scale manifests itself more prominently than before. The threat has become real; the opening key's identity is subverted. No (re)capitulation! 
on and informed by the problems that occur when an attempt is made to subsume the capricious course of the melody under a macroformal division, bringing in this recently discovered manuscript displaces the attention again to a paratextual element of Debussy's composition as set down in the score: the breath marks.

\section{5}

Fifth in(-)formation. The Syrinx score, published by Jean Jobert in 1927, was edited by the eminent flutist, Marcel Moyse. It is most likely that he added the bar lines in order not to frighten amateur flautists who wanted to perform the piece. Perhaps he also inserted some slurs. But the most important change Moyse made was in the number of breath marks.

How do we know this? Research in the early 1990s brought to light a manuscript, signed and dated November 1913, which may be the score from which Louis Fleury played at the December 1913 performance. ${ }^{11}$

The manuscript presents some differences with respect to the Jobert edition, differences regarding dynamics, agogics and breathing, and is therefore very significant in connection with a reading of La flutte de Pan/Syrinx. In the manuscript there are only three breath marks: at the end of bar 2 and in the middle of bars 4 and 14, while in the Jobert edition there are as many as seventeen breath marks. ${ }^{12}$ The breath marks added by Moyse became conventional, given that all the editions that followed each other over the years (until the one by Ljungar-Chapelon and Stegemann of 1992 which is based on the manuscript instead) follow, at least on this point, the Jobert version. This is perhaps also due to the fact that, as flutist Trevor Wye asserts, Moyse initially refused to allow his name to appear as editor of the piece, declaring that he had only clarified some inconsistencies. This may have induced subsequent editors and flute-players to think that the breath marks of the Jobert version were directly emanating from Debussy himself. Only many years later did Moyse reveal that several breath marks (for example, those at the end of bars 16 and 25) were added by him because of his own personal difficulties (see note 11). In the explanatory notes to 'his' edition, Wye quotes his old teacher Moyse: "I remember Debussy asking me not to breathe here, but I couldn't do it. [...] For me it's not possible." So, though, again according to Moyse, he greatly appreciated the breaths at the end of bars 28 and 29, Debussy disapproved of the 'pause' in bar 25. It appears that Debussy desired a more relaxed, uninterrupted melodic movement, a more fluid and less fragmentary performance. By avoiding this breath mark in bar 25 , a continuity in tension is produced between the repeat of the initial motif in bar 26 and the preceding part ('en animant peu à peu'), a tension that is increased by the lengthening of the B flat (Curinga 2001).

11 The manuscript, inscribed with cues from Mourey's poem, was located in Brussels in the private collection of Madame Hollanders de Ouderaen and found by Swedish flute player Anders Ljungar-Chapelon and German musicologist Michael Stegemann. However, the handwriting does not resemble the ones found on other Debussy manuscripts, so it probably does not concern the original text here. According to Stegemann, the inclusion of excerpts from the Mourey text, indicating the exact point where the piece should occur within the body of the scene, suggests that the manuscript may be a copy most likely penned down and used by Louis Fleury. The manuscript itself contains lengthwise folds as though it may have been fitted into a flute case. Unfortunately, no documented manuscript in Fleury's handwriting is available to verify his possible authorship (Ewell 2004: 3-4).

12 Three remarks, all related to the significant difference between the breath marks present in the manuscript and the Jobert edition should be made here. First, in his scores for wind instruments, Debussy did not mark every breath, only those most meaningful musically. The commas in the manuscript may even refer to a purpose other than simply indicating an in-breath. The first comma at the conclusion of the second bar is inscribed together with a fermata, most probably articulating the musical significance of the first two measures. The remaining two commas in bar 4 and 14 are placed at points of alteration in rhythmic motives, separating a duple from a triple motive. Second remark: there is an explanation for the almost excessive number of breaths that Moyse indicated: he had a personal breathing problem contracted in his childhood, and so prepared the edition to match his own limitations (Curinga: online). Third, the breath mark at the end of bar 8 in the Jobert edition seems to be quite valid. In the theatrical version, the acting intervenes at precisely this point with the Oread who, without any accompaniment, says her lines "Tais-toi, contiens ta joie, écoute" [Be silent, contain your joy, listen]. There, the music actually breaks off, corresponding to the conclusions of the analysts with regard to the formal divisions. To make a short pause at that point is also confirmed by the double bar in the manuscript. 
The performance of the piece as a single unbroken discourse, as advocated by Curinga a discourse that should only be interrupted by the oread summoning the naiad to silence (after bar 8: see note 11) - thus seems to be lent support by Debussy's preference for long phrases unbroken by breathing. ${ }^{13}$

Are we entering a discussion about Truth? About the genuine intentions of the Author? About authentic and false interpretations? About the necessary quest for origins? Though we should never be exonerated from searching for and examining detailed information and reliable historical sources, the discussion I am taking up here is not immediately translatable to questions about truth, intentions, interpretations, and origins. The question that arises while dwelling upon Debussy's composition, while (re)reading the score and investigating the intertextuality of La flutte de Pan/Syrinx is first of all related to the heart of Western thinking, formed by hierarchically ordered binary oppositions. What is questioned here, through analyzing $L a$ flute de Pan/Syrinx, is analysis itself, as it has taken shape in the dominant canon of music theory, favoring the visual and the measurable at the expense of unanticipated but relevant bodily experiences. What comes to mind is an excerpt I recently reread in Suzanne Cusick's essay 'Feminist Theory, Music Theory, and the Mind/Body Problem'. In this excerpt, she briefly touches upon a passage from the chorale prelude on Aus tiefer Not in Bach's Clavierübung, Part III (BWV 686). The most physically challenging moment in this church organ piece, the moment where neither foot nor hand can rest long enough to balance the body, appears at the phrase "Send me the grace my spirit needs". Neither harmonic nor contrapuntal analysis would identify this short passage as critical to the work's meaning. Yet, it is (inaudibly) marked by the performer's body's craving for a place to balance and thereby absolutely meaningful. Cusick concludes that traditional musical analysis often negates the possibility of performers as receivers of meaning: "To deny musical meaning to things only the performers of a work will know implicitly denies that performers are knowers, knowers whose knowledge comes from their bodies and their minds [...]. To deny musical meaning to purely physical, performative things is in effect to transform human performers into machines for the transmission of mindmind messages between members of a metaphorically disembodied class, and, because disembodied, elite" (Cusick 1998: 48-9). ${ }^{14}$

Breath marks: paratextual elements occurring in the margins of a musical text; supplements, neglected by most theorists, at least as regards La flîte de Pan/Syrinx. ${ }^{15}$ Neglected because writing on music is (too) often writing on ideas: musico-technical (melodies, harmonies, form), institutional (classical music versus jazz, pop, and 'world music'), historical (Early Music versus Modern Music, Baroque versus Romanticism), dialectical (music characterized as an art in time versus a spatial art); in short, music is usually presented as flowing in a bodiless world. Such a discourse leaves some of music's most profound characteristics untouched: its embodiment, or, better still, the fact that music has something to do with air, with vibrating air, with breath

\footnotetext{
13 It should also be remembered that Fleury, the dedicatee of the piece, was famous for his ability to play very long phrases.

14 It is exactly examples like this one taken down by Cusick that legitimate something like Practice Based Research (PBR), the opportunity of a $\mathrm{PhD}$ degree afforded to artists. Cusick's description of the activities of 'performers as knowers' precisely opens up a space for interpretation and musical meaning that is usually foreclosed for music theorists and musicologists. More than that, the latter often obstruct this way of analyzing music, pre-occupied as they are with scores instead of performances. It is exactly here that the surplus value of PBR as well as its necessity shows itself. It seems like the 'traditional' analysts are not concerned with the possible repercussions of their work on performances.

15 The only theorist who writes about them is Jean-Jacques Nattiez in a famous analysis of Syrinx in his Fondements d'une sémiologie de la musique from 1975. The problem with this analysis, however, is that Nattiez - basing himself on the Jobert edition - calls all the breath marks 'pauses' and asserts they are fundamental for the segmentation of the piece (Nattiez: 340). This segmentation at least seems to contradict Debussy's preferences and the instructions in the manuscript.
} 
Music is the art of breathing. ${ }^{16}$ Music is born out of breath, breath that Indian thought calls life (prana). Music thus springs from the breath of the living body. Music, in fact, is this living and breathing itself. Breathing therefore deconstructs the border between music and not-yet-music (silence?). Breathing (also) deconstructs the border between sound and silence: breathing is the moment where sound and silence coincide. It is nearly without sound, but it is never soundless, never motionless. What is heard is the birth of music. And how can the birth of music not be part of music, of 'itself'? ${ }^{17}$

\section{6}

Sixth in(-)formation. ${ }^{18}$ Six times around music, around La flûte de Pan/Syrinx. Six times turning merely around it, proceeding along its outskirts, engaging in its surroundings: title, silence, discourse, theater ... and breath marks. Like the others, both outside and inside, neither outside or inside Debussy's composition for solo flute. And, like the others, undoubtedly influencing its meaning.

Breath marks. They appear to be essential for marking the rhythm of the musical speech in that they underline moments of continuity or discontinuity. They (too) determine the unfolding of the (musical) story, creating emphasis on certain elements, marginalizing others. As such, they also reinforce the relation between music and poetry. ${ }^{19}$ What before was just a means to construct forms and structure, now becomes an 'essential' feature.

And is it not at this point of arrival, this point where we all turn into Pans, groping around in the vacuous void, confronted with permanent reversals and dislocations, not precisely the (in-)form(ation) of La flute de Pan/Syrinx? This music first of all oscillates between ornamentation - as it accompanies a theater play, a poem - and being ornamented itself - by that same poem or at least by its title. The one informs the other, gives it its proper place, frames it. Second, could we state - impudently and imprudently perhaps - that everything (which means: nothing) 'within' La flûte de Pan/Syrinx becomes ornament? The ornaments of the first few bars, the whole tone scale with $\mathrm{D}$ flat as the tonal center, seem to become ornamented themselves by that other whole tone scale (with the B flat as its tonal center) at the end of the piece. This music only consists of ornaments, that is, of inessentials, of secondary materials. The one

16 In Between East and West, Luce Irigaray criticizes the whole Western culture of its l'oubli du souffle or 'breath oblivion' and tries to find the way back to a source that is called breath; not a concept of breath, but a practice. Irigaray shows how Westerners remain passive when it comes to breathing. She calls and defends an active way of breathing, a respiration in full consciousness.

17 So, also from a phenomenological point of departure, one should conclude that La flute de Pan/Syrinx doesn't begin with the A-B interval; it begins with breathing.

18 Heedful of one of its meanings, I am (perhaps) obliged by now to offer some information about the main title of this essay, a title that consists of a word (or actually several words) that also functions as a mark for the various, quasi-detachable sections presented here. First of all, this essay in some way or another informs; it gives information, primarily about a composition for solo flute by Claude Debussy but also about several (literary and philosophical) connotations that haunted and inspired me while writing around it and listening to it. Second, however 'open' I would like this essay to be, I am perfectly aware that it also forms, that is, provides structures of talking to/with music; in short, without expending too many words, every writing also disciplines. But this disciplining dimension is never complete, never all-embracing. In the forming informing, something unformed (in-forme in French) remains or escapes, a rest, a redundancy, a noise (a rustling reed perhaps?), a supplement: ce qui reste a force de la musique.

19 According to Laurel Astrid Ewell, Debussy appears to correlate poem and music in La Flûte de Pan/Syrinx by the incorporation of music whose characteristics illustrate the literal meaning of certain phrases or words: "The resulting interaction between the two entities generates an intensified dramatic presentation in which the music adds to the interpretation and understanding of the poem" (Ewell 2004: 56). As an important example she mentions the breath following the fermata tied to a half-note in bars $24-25$ because it articulates the conclusion of a larger compositional process and a section of illustrative music, metaphorical of the poetry. Additionally, the pause after the first B flat in bar 24 also represents the conclusion of the music depicting the four nymphs.

Although I agree with Ewell that Debussy was definitely searching for a music that would match Mourey's poem (his letter from November 17,1913 seems to prove this as he writes: "So far I have not found what is needed ... because a flute singing on the horizon must contain its emotion all at once! That is, there is no time for repetitions, and exaggerated artificialness will coarsen the expression since the line or melodic pattern cannot rely on any interruption of color. Please tell me, very precisely, after what lines the music starts. After several attempts, I think that one must stick to the Pan flute alone, without any accompaniment. This is more difficult but more [logical - crossed out in the autograph] according to nature."). I'm not sure if her examples are convincing as they seem to contradict the emphasis Debussy gives on long, uninterrupted musical sentences (see above). My alternative, however, to thinking the relation between poem and music will remain here rudimentary, tentative, and circumspect. 
for the benefit of the other, continuously changing places, an endless reversal of hierarchies. Third, in La flute de Pan/Syrinx, the art of hinting, indicating, and beckoning is taken to an extreme limit. Instead of long-drawn-out melodies, only some arabesques and decorations emerge, resolving the (Classical and classical) musical syntax, finally arriving at the simple appearance of a single tone. ${ }^{20}$ What before was a means to build - a melody, a harmony - now becomes 'the matter itself' (Hirsbrunner, p.197). ${ }^{21}$ Fourth, some words should be spent on the aspect of repetition. In his correspondence to Mourey, Debussy writes: "Je veux dire, qu'on a pas le temps de s'y reprendre." There is no time to propose repetitions, which is of course a limitation, a 'containment'; the piece can be nothing else but short, being constrained by the temporal margins set by the poetic text (Curinga 2001). And yet, one only has to listen superficially or glance at the score to experience a profusion of (varied) repetitions, both melodically and rhythmically. (In footnote 9, I already indicated that the opening motif B flat-A-B is repeated 7 times.) What Debussy was denied on a macro scale infiltrates the piece on a micro level. The piece is a recurrence in itself, constantly resuming certain motifs, often proposing new sequels, quenched in one breath. However, as Debussy preferred La flute de Pan/Syrinx as a (more or less) single unbroken discourse, the repetitions cannot simply be considered renewed beginnings, new onsets, fresh starts. His preference for long-breathing phrases lets every recurrence appear as a non-equal equality: with the absence of (intended) breathing spaces, its differences, its transformations, its developments are emphasized. Appearing in a different context, appearing in a context already permeated by 'repetitions', the repeated motifs also emerge 'for the first time'. ${ }^{22}$ They sound in a space between repetition and difference, between identity and alteration. On one hand, a certain self-identity is required to permit recognition and repetition. Certain consistencies must be maintained in order for a motif to be identifiable as a motif. On the other hand and at the same time, the possibility of repetition never permits a certain musical motif to be a unity identical to itself. Because its context is always different, it is never absolutely the same: "repeated, the same line is no longer exactly the same," Derrida writes (Derrida 1978: 296). Alteration is always already at work within the inner core of the motif when the identical is repeated.

Binary logic, thinking in hierarchical relations and clear opposites, and logocentrism break down in and on La flute de Pan/Syrinx. Deconstruction. Deconstruction in music.

\section{7}

Hors d'oeuvre. In Plato's Symposium, Eryximachus dismisses the (female) flute-player so that he can have a profound conversation with his (male) guests. After all, the "voice of the flute' - a non-discursive sonority - drowns out the voice of the Logos, of a logocentrism characterized by clear-cut, hierarchically organized, oppositions. The flute impairs the ethical powers and causes one to lose oneself in an orgiastic flush. In the desire for transparency, sound (music) disturbs the relative quiet in which Eryximachus and his friends want to think or philosophize. The flute produces (mimics) a human voice without logos, and the moment a

20 "Thanks to the arabesque, which has an open structure and derives from a decorative, ornamental and figurative conception, that of Jugendstil, music can overcome the mechanical stiffness and achieve that 'free' art, the result of the spiritual correspondence between art and nature, at which the French composer aimed" (Curinga: online).

21 More in general one could state that the articulative modes of expressing meaning of the Classical musical syntax - the elements of sentence, period, and hybrid - are significantly modified in the (later) works of Debussy through his use of modal-chromatic language and persistent preference for asymmetrical and open-ended phrase structures, marked with half-cadences. Debussy's musical gestures suggest new interpretations of formal function and expressive import.

22 Derrida speaks in this respect about iteration or iterability (the possibility of iteration). The stem 'iter' means 'again'. But, at the same time, Derrida suggests that this word 'iter' comes from the Sanskrit word 'itara', meaning 'other'. Along this line, we enter a paradoxical logic that ties repetition to alterity. 
human voice is without logos it becomes demonic and abysmal; it emanates a heterogeneous power.

Logocentrism, on the contrary, has no sound. Its voice is silent; it is not acoustic, it has no spatiality. ${ }^{23}$ Logocentrism can, otherwise, be understood as the repression of the corporeality of sounds; it is an oppression of music, of breathing, of the non-formed or informe. Indeed, all this has a disruptive effect on the ideality, the unambiguousness of meaning. ${ }^{24}$ There is no room for sonority, a sonority that mainly excludes Logos as it interferes with the ideality of the intended (homogeneous, transparent) meaning (vouloir dire).

By accommodating the phenomenal aspect of sound (of sounds simultaneously outside and inside the realm of music), Debussy's work gives a voice to the unsaid, the heterogeneous, the informe. La flûte de Pan/Syrinx gives deconstruction a real voice. The flute is welcomed and has something to say: it speaks of the unspeakable. As it interrupts many familiarities, it speaks disorderly, 'out of tune'. Do we allow ourselves to become seduced by its voice like the anonymous river nymph, or are we still descendants of Eryximachus? In either case: beware of the consequences!

\section{Literature}

Bloch, Ernst (1986). The Principle of Hope. Cambridge (MA): MIT Press.

Cobussen, Marcel (2002). Deconstruction in Music. Rotterdam: www.cobussen.com.

Cone, Edward T. (1966). Musical Form and Musical Performance. New York: Norton.

Curinga, Luisa (2001). 'Parallel Paths: Historical-Documentary and Analytical Contributions as a Basis for the Performance of Debussy's Syrinx'. In: Analitica, vol. 2, nr. 2. http://www.muspe.unibo.it/gatm/Eng/Vol2_2/curniga_eng_2_2.htm.

Cusick, Suzanne (1998). 'Feminist Theory, Music Theory, and the Mind/Body Problem'. In: Krims, Adam (ed.). Music/Ideology. Resisting the Aesthetic. Amsterdam: G + B Arts.

Derrida, Jacques (1978). Writing and Difference. London: Routledge.

Derrida, Jacques (1982). Margins of Philosophy. Chicago: Chicago University Press.

Derrida, Jacques (1987). The Truth in Painting. Chicago: University of Chicago Press.

Ewell, Laurel Astrid (2004). A Symbolist Melodrama: The Confluence of Poem and Music in Debussy's La flûte de Pan. Virginia: West Virginia University. https://etd.wvu.edu/etd/etdDocumentData.jsp?jsp_etdId=48.

Genette, Gérard (1991). 'Introduction to the Paratext' [translation of Marie Maclean]. New Literary History, 22: pp 261-272.

Han, Byung-Chul (1997). 'Derrida's Ohr'. In: Musik \& Ästhetik, Heft 4. Stuttgart: Klett-Cotta.

\footnotetext{
23 Rarely have philosophers made themselves known as sound enthusiasts. In addition to Plato, others have condemned music and/or sound. "Danger in the voice. Sometimes in conversation the sound of our own voice confuses us and misleads us to assertions that do not at all reflect our opinion," Nietzsche writes in Human, All Too Human (aphorism 333).

In this respect, I would also like to refer to a poem by John Keats: 'Ode on a Grecian Urn'.

Depicting the figures on an old vase, the beginning of the second strophe seems to refer to the picture of a musician or a music instrument: "Heard melodies are sweet, but those unheard are sweeter; therefore, ye soft pipes, play on; not to the sensual ear, but, more endear'd, pipe to the spirit ditties of no tone." Keats' noble thought that the silence of a flute (player) is great because it allows for so many different sounds, an inexhaustible source of new compositions, seems deceitful to me. If an inaudible reference to music is preferred above the actual sounding of an instrument or voice, music is silenced. Confined to the subject's interiority, innocuous to the ear and the rest of the body, music is refused, because it might disrupt the perfect sounds of the mind. (Is Keats approaching Plato here?)

24 See for a more extensive and intensive discussion of this topic Byung-Chul Han's essay 'Derrida's Ohr' (in: Musik E Ästhetik, Heft 4. Stuttgart, 1997) and my online dissertation (Cobussen 2002: section 'Derrida's Ear').
} 
Hillis Miller, J. (1999). 'The Critic as Host'. In Bloom, Harold (et al.), Deconstruction \& Criticism. New York: Continuum.

Hirsbrunner, Theo (1981). Debussy und seine Zeit. Laaber: Laaber-Verlag.

Irigaray, Luce (2002). Between East and West. From Singularity to Community [translation of Entre Orient et Occident. Paris, 1999]. New York: Columbia University Press.

Littlefield, Richard (2001). The Margins of Musical Analysis. Helsinki: Semiotic Society of Finland.

McClary, Susan (1991). Feminine Endings. Music, Gender, and Sexuality. Minneapolis: University of Minnesota Press.

Nattiez, Jean-Jacques (1975). Fondements d'une sémiologie de la musique. Paris: U.G.E.

Taylor, Mark C. (1984). Erring: a Postmodern A/theology. Chicago: University of Chicago Press. 